\title{
Corporate governance in Indian banks post subprime crisis
}

Sunaina Kanojia

University of Delhi

Sawaliya Priya

University of Delhi

\section{Recommended Citation}

Kanojia, S., \& Priya, S. (2016). Corporate governance in Indian banks post subprime crisis. International Interdisciplinary Business-Economics Advancement Journal, 1(2), 50-62. 


\title{
Corporate Governance in Indian Banks Post Subprime Crisis
}

\author{
Sunaina Kanojia ${ }^{1}$ and Sawaliya Priya ${ }^{2}$
}

\author{
Delhi School of Economics \\ University of Delhi, India \\ 1'sunainakanojia@gmail.com \\ Mata Sundri College \\ University of Delhi, India \\ 2priyasawaliya@gmail.com
}

\begin{abstract}
This paper attempts to unearth quality of corporate governance practices of Indian Banking sector and highlight whether the corporate governance practices of listed public and private sector banks are symmetric post subprime crisis. The study examines that whether the key corporate governance factors like capital adequacy ratio, board size, number of independent directors and CEO duality affects the performance of banks. In addition to this, the paper goes on to find the essence of shareholding by non-executive directors and the regularity of directors in attending the board meetings. Further, for the perusal of corporate governance practices followed in the Indian banking sector a corporate governance index has been compiled from the data of all listed Indian banks. Moreover, the paper endeavors to exhume any relationship between the educational qualification of directors and its contribution on the banks' performance, if any. The results provides an insight of the corporate governance structure of Indian banking sector and exhibit that the public and private sector banks have asymmetric corporate governance practices post subprime crisis. The empirical results of multiple regression analysis demonstrate a positive impact of corporate governance factors on Indian bank's performance.
\end{abstract}

Keywords: corporate governance, banks' board, board size, board monitoring

\section{Introduction}

Corporate governance is a way of life that moulds and directs the roles, responsibilities and rights of management and board of directors of organisations with a view to achieving the corporate objectives of the organisation and capturing the interests of various stakeholders. Corporate governance practices are relatively a new issue in Indian society and came into prominence in the 90's due to securities scam in 1992 and disappearance of number of companies after rising capital in stock market in mid-90. In light of the Asian financial crisis, high profile scandals in Russia and Latin America, and the increased focus placed on governance practices in the Middle East and North Africa, corporate governance has been brought to the forefront and has become a strategic issue for businesses in the increasingly globalized economy. Good corporate governance is required because of the existence of agency problems caused by the separation of ownership of resources and managing those resources Jensen and Meckling (1976) and minimize the conflict of interest between agents and principals. Sharma (2010a; $2010 \mathrm{~b}$ ) opines that corporate governance is the way organizations are managed and controlled 
and aims to achieve corporate excellence. Promoting the good corporate governance in banking sector is crucial to its economic performance. Therefore the extent to which this performance is achieved vis-a-vis corporate governance in the banking sector demands an in-depth exploration investigation and perhaps it is also the focus of this study. The debate of corporate governance goes decades back but the advancements in the recent past have changed the paradigm of this debate. The studies of Qu, Jiang, and Zhang (2012) investigated empirically the performance of banks in the BRIC countries (comprising Brazil, Russia, India, and China) during the financial crisis. The period under study was from 2003 to 2010, and it was found that, from 2007 to 2008, there was a significant decline in the banking efficiency due to the crisis. Similarly, GarciaMeca, Garcia-Sanchez, and Martnez-Ferrero (2015) have attempted to analyze the effect of board diversity (gender and nationality) on performance in banks and found its positive impact on banks' performance. Dalwai, Rohaida, and Siti (2015) evaluates existing studies on the relationship of corporate governance with firm performance in different regions and address the need for similar analysis for the Gulf Cooperation Council (GCC) sector as well.

\section{Theories of Corporate Governance}

There is no single universe theory of corporate governance. Development of corporate governance is a global occurrence, and a complex area including legal, cultural, ownership, and structural differences. Thus, some theories might be more appropriate and relevant to some countries than others or, more relevant at different times depending on what stage an individual country, or group of countries, is at. The theories which define the corporate governance in different ways are agency theory, stewardship theory, stakeholder theory, resource dependency theory, social contract theory and legitimacy theory. The essence of the agency problem is the separation of management and finance, or as defined in more standard terminology, the separation of ownership and control (Shleifer \& Vishny, 1997). Stewardship theory suggests the unification of these two roles in one person who, as the steward of the organization, would act in the organization's best interest. It has been empirically established that the returns, for an organization, improved by having both the positions (the CEO and the Chairman) combined rather than separated (Donaldson \& Davis, 1991). According to the stakeholder theory the corporation must be run in the interest of stakeholders. According to the resource dependency rule, the directors bring resources such as information, skills, key constituents (suppliers, buyers, public policy decision makers, social groups) and legitimacy that will reduce uncertainty. Social contract theory as well as legitimacy theory are based upon the notion that there is a social contract between the society and an organisation.

\section{Formulation of Hypothesis}

Adams and Mehran (2003) stated that the practices of corporate governance in the banking sector differ from other sectors because of their characteristics as a regulated industry. Gillan, Hartzell, and Starks (2003) in their work hypothesized that corporate governance structures differ systematically across industries and firms due to differences in the costs and benefits of the monitoring mechanisms. Li and Harrison (2008) found that national culture has a dominant influence on corporate governance structure. Nippani, Vinjamury, and Bathala (2008) established that there exist significant differences between the governance structures of banks based on their size and that banks' stock market returns are significantly influenced by board composition. Cheung, Stouraitis, and Tan (2010) found that the quality of corporate governance is very significant in explaining future company stock returns and risk. Kanojia (2010) 
endeavored to emphasize that if the board of directors contribute to the company at regular interval, it improves the performance of banks. Utama and Musa (2011) shows that corporate governance practice, bank size and capital adequacy ratio have positive influence on bank performance in Indonesia. Wang, Lu, and Lin (2012) proved that corporate governance is important for the operating performance of BHCs. Panchasara and Bharadia (2013) showed that the corporate governance (CG) disclosure practices are positively associated with financial performance of Indian Banks by using the financial and non-financial parameters explained in the 'Guidance on Good Practices in Corporate Governance Disclosure' issue by the ISAR (International Standards of Accounting and Reporting). Sarpal (2014) found the significance of firm size by revealing that the relationships between some of the selected voluntary board practices do vary according to the firm size status. Madhani (2015) has found that board committees are major contributor to overall corporate governance and disclosure practices of Indian firms which help to understand that apart from statutory requirement of audit committee there is also a need for remuneration as well as nomination committees to improve the overall standard of corporate governance. After reviewing the literature we found that the banks with poor corporate governance practice performed worse and led to the crisis (Chambers, 2009; Ross \& Crossan, 2012). According to Indian Banking Regulation Act 1949 not less than 51\% of the total number of the board of directors comprising members with demonstrable professional and other experience in specific sectors like accountancy, agriculture and rural economy, banking, co-operation, economics, finance, law, small-scale industry, any other matter the special knowledge of, and practical experience in, which would, in the opinion of the Reserve Bank of India, be useful to the banking company. De Jonghe, Disli, and Schoors (2012) found that CEO non-duality, education level of executives, and a business education of the CEO and/or the chairman all relate to much better risk/return efficiency in the post-crisis period for banks. Their findings suggest that strict regulation in combination with improved board structure and composition might go a long way to improve the risk/return profile of banks. Largely it has been found that there exists a strong relation between governance structure, agency problem and firm's performance level. Most of studies indicate better governed companies are more profitable and have higher firm value especially in countries with weak legal environments. Prior studies of Mace (1971); Pfeffer (1972); Lipton and Lorch (1992); and Jensen (1993) highlighted contrasting results of board size and effective monitoring. It has been empirically tested that large boards are generally less effective as compared to smaller boards due to communication and coordination advantages. (Jensen, 1993; Lipton \& Lorch, 1992). In view of important findings discussed above the present paper aims to gauge the performance of all listed Indian banks post subprime crisis and its dependency, if any on corporate governance practices. Further, it attempts to examine that whether the key corporate governance factors highlighted in the banking literature like capital adequacy, board size, number of independent directors and duality affects the performance of banks. In addition to it the paper attempts to find essence of shareholding by non-executive directors and regularity of directors in attending board meetings. The objective of this paper is to find that whether corporate governance affects the banks' performance during the post crisis period and providing in-depth knowledge about the corporate governance practices along with the impact of education qualification of NEDs on the performance of Indian banking sector. The study proposes the following alternate hypothesis:

- $\mathrm{H}_{\alpha 1}$ : The capital adequacy ratio has a significant effect on the bank performance.

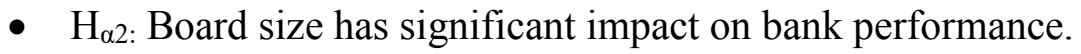


- $\mathrm{H}_{\alpha 3}$ : Attendance rate of directors at board meeting has a significant influence on bank performance.

- $\mathrm{H}_{\alpha 4}$ : Bank performance is significantly affected by number of independent directors on board.

- $\mathrm{H}_{\alpha 5}$ : Number of shares held by NEDs has a significant effect on the bank performance.

- $\mathrm{H}_{\alpha 6}$ : Bank performance is significantly affected by CEO duality.

- $\mathrm{H}_{\alpha 7}$ : Education Qualification of NEDs has a significant influence on bank performance.

\section{Data and Methodology}

This paper is based on the perusal of secondary data obtained from all the listed public as well as private sector banks in India. The relevant information about the key factors of corporate governance has been obtained through content analysis of the annual reports published by the banks. India has forty listed banks during the sample period of four years post subprime crisis 2008-09 to 2011-12. The data collected from content analysis of one hundred and sixty annual reports has been categorized to facilitate descriptive analysis and to apply multiple regression analysis thereon. The key corporate governance factors which exhibit significant correlation have further been regressed with the independent variables of board size, number of independent directors, shareholding by non-executive directors, duality, capital to risk asset, educational qualification of the board and ROA, ROE, ROI as proxy to bank performance. ROA (Return on Assets) equals after tax net income (profits) divided by average total assets of bank (Lin \& Zhang, 2009; Saunders \& Cornett, 2005) and reflects the deployment of bank assets to yield its income (Adams \& Mehran, 2003; Andres \& Vallelado, 2008). The central bank has set ROA as proxy for profitability while giving reference to the Indian banking conditions. Further, total assets as a denominator is very sensitive to the accounting methods used by the banks. The study also uses ROE (Return on Equity) as a proxy of bank performance relevant to shareholder's investment (Berger, Clarke, Cull, Klapper, \& Udell, 2005; Kim \& Rasiah, 2010). ROI (Return on Investment) is one of the determinants of key performance indicators of private sector banks. In order to evaluate the cause and effect of independent variables on the performance proxies the following regression equations have been formulated.

$$
\begin{aligned}
& \mathrm{ROE}=\alpha+\beta 1 \text { BOARD_SIZE }+\beta 2 \text { ATTENDANCE }+\beta 3 \text { SHARES }+\beta 4 \text { ID }+\beta 5 \text { CRAR }+\beta 6 \text { CEO_DUALITY }+\varepsilon \\
& \text { ROA }=\alpha+\beta 1 \text { BOARD_SIZE }+\beta 2 \text { ATTENDANCE }+\beta 3 \text { SHARES }+\beta 4 \text { ID }+\beta 5 \text { CRAR }+\beta 6 \text { CEO_DUALITY }+\varepsilon \\
& \text { ROI }=\alpha+\beta 1 \text { BOARD_SIZE }+\beta 2 \text { ATTENDANCE }+\beta 3 \text { SHARES }+\beta 4 \text { ID }+\beta 5 \text { CRAR }+\beta 6 \text { CEO_DUALITY }+\varepsilon \\
& \mathrm{ROE}=\alpha+\beta_{1} \text { GR }+\beta_{2} \mathrm{PG}+\beta_{3} \text { DOCT }+\beta_{4} \text { PROF }+\varepsilon \\
& \mathrm{ROA}=\alpha+\beta_{1} \mathrm{GR}+\beta_{2} \mathrm{PG}+\beta_{3} \mathrm{DOCT}+\beta_{4} \mathrm{PROF}+\varepsilon \\
& \mathrm{ROI}=\alpha+\beta_{1} \mathrm{GR}+\beta_{2} \mathrm{PG}+\beta_{3} \mathrm{DOCT}+\beta_{4} \mathrm{PROF}+\varepsilon
\end{aligned}
$$

Where:

- $\quad \alpha$ and $\beta$ : constant and coefficient of applied model respectively.

- $\varepsilon$ : all the factors which affect the dependent variable but not included in the model.

- BOARD_SIZE: total number of directors in the bank

- ATTENDANCE: average attendance rate of the directors in the board meetings

- SHARES: percentage of shares held by NEDs 
- ID: percentage of Independent directors in the board

- CRAR: Capital to Risk Assets Ratio

- CEO_DUALITY: dummy variable, its value is 1 when there is no duality and 0 in case of duality.

- GR: when number of NEDs who are graduate, is equal to or greater than average, then we put 1 and 0 otherwise.

- PG: when number of NEDs who are post graduate, is equal to or greater than average, then we put 1 and 0 otherwise.

- DOCT: when number of NEDs who have the degree of M.phil or PHD, is equal to or greater than average, then we put 1 and 0 otherwise.

- PROF: when number of NEDs who have the professional degrees, is equal to or greater than average, then we put 1 and 0 otherwise.

\section{Analysis and Findings}

The results in Table 1 of descriptive analysis shows that the average ROA is 1percent with minimum and maximum value being -0.4 percent and 1.63 percent consecutively. The average ROE is 15.47 percent with a minimum and maximum value consecutively -4.59 and 22.69 percent and the mean value of ROI is 6.91 with minimum of 6.09 and maximum of 7.57 percent. The minimum values are exhibiting the status just after the subprime crisis and there after the values tend to be positive as well as increasing showing that the sector maintains the assets and returns to the shareholder. We may state that except the year succeeding the subprime crisis, the banking sector in India has been surviving with an above average growth and operates in risk averting conditions. The average Tier I capital is 9.87 percent with a minimum of 6.86 and maximum of 16.67 percent and the average of CRAR is 13.83 percent with minimum and maximum value consecutively are 11.70 and 18.92 percent. This is perhaps due to the requirements of Central bank that the sector maintains a minimum CRAR of 9 percent and Tier I capital of 6 percent. Further, it indicates that Indian banks were well capitalised during the post crisis period and are conservative in their capital structure policy. The average growth rate of Indian bank is 24.45 percent with a minimum of -7.36 and maximum of 80.83 percent. The range of growth exhibited by the statistics highlight that some banks in the sample are extremely profitable but a few of them still have a questionable bottom line.

Average NPA is 0.89 percent which is not high, with minimum and maximum value consecutively is 0.07 and 1.92 percent which implies the banking system in India in respect of securitization of their assets is doing well. Although, there have been times especially during the 1980-90 wherein NPA was a pan India problem. The data reveals such scenario has been a past and problem of NPA has been insignificant during the sample period. The stringent regulations of central banks may be credited for this advancement. The average board size in our sample is 10.68 with the maximum of 14.25 which indicates that the Indian banks follow the guidelines of RBI that all the banks should have minimum of 10 board members. The clause 49 of the listing agreement in India requires that every board shall meet at least four times a year with a gap of not more than four months between two meetings and the sample of the study shows that average attendance rate at board meetings is 8.18 with the maximum of 12.01 and minimum value of 4.88 which means that banks follow this requirement way above the statutory norms. Average percentage of independent directors in board is 68.85 percent with a minimum of 36.36 and maximum of 91.22 percent. 
Table 1: Descriptive Statistics

\begin{tabular}{llcccc}
\hline & N & Minimum & Maximum & Mean & Std. Deviation \\
\hline ROE (\%) & 40 & -4.59 & 22.69 & 15.466 & 5.63985 \\
ROA (\%) & 40 & -0.4 & 1.63 & 1.002 & 0.41783 \\
ROI (\%) & 40 & 6.09 & 7.57 & 6.9101 & 0.3965 \\
Tier I (\%) & 40 & 6.86 & 16.67 & 9.8732 & 2.23233 \\
CRAR (\%) & 40 & 11.7 & 18.92 & 13.8334 & 1.72068 \\
Growth (\%) & 40 & -7.36 & 80.83 & 24.454 & 17.02644 \\
NPA (\%) & 40 & 0.07 & 1.92 & 0.8905 & 0.4908 \\
board size & 40 & 7 & 14.25 & 10.675 & 1.45478 \\
attendance & 40 & 4.88 & 12.01 & 8.182 & 1.50587 \\
Shares (\%) & 40 & 0 & 2.4125 & 0.13712828 & 0.445400439 \\
ID (\%) & 40 & 36.36 & 91.22 & 68.8536 & 13.59183 \\
\hline
\end{tabular}

Source: Research Compilation

Table 2: Pearsons' Correlation Analysis

\begin{tabular}{|c|c|c|c|c|c|c|c|c|c|c|}
\hline & ROE & ROA & ROI & board size & attendance & ID & shares & CRAR & growth & NPA tier I \\
\hline ROE & 1 & & & & & & & & & \\
\hline ROA & $\begin{array}{l}.771^{* *} \\
0\end{array}$ & 1 & & & & & & & & \\
\hline ROI & $\begin{array}{l}.368^{*} \\
0.019\end{array}$ & $\begin{array}{l}0.272 \\
0.089\end{array}$ & 1 & & & & & & & \\
\hline board size & $\begin{array}{l}0.264 \\
0.099\end{array}$ & $\begin{array}{l}0.134 \\
0.41\end{array}$ & $\begin{array}{l}0.093 \\
0.57\end{array}$ & 1 & & & & & & \\
\hline attendance & $\begin{array}{l}0.125 \\
0.442\end{array}$ & $\begin{array}{l}0.081 \\
0.62\end{array}$ & $\begin{array}{l}0.012 \\
0.941\end{array}$ & $\begin{array}{l}.721^{* *} \\
0\end{array}$ & 1 & & & & & \\
\hline ID & $\begin{array}{l}0.15 \\
0.355\end{array}$ & $\begin{array}{l}-0.015 \\
0.928\end{array}$ & $\begin{array}{l}0.042 \\
0.797\end{array}$ & $\begin{array}{l}-0.125 \\
0.444\end{array}$ & $\begin{array}{l}-0.217 \\
0.18\end{array}$ & 1 & & & & \\
\hline shares & $\begin{array}{l}-0.046 \\
0.777\end{array}$ & $\begin{array}{l}0.075 \\
0.644\end{array}$ & $\begin{array}{l}0.204 \\
0.207\end{array}$ & $\begin{array}{l}-0.054 \\
0.739\end{array}$ & $\begin{array}{l}-0.006 \\
0.972\end{array}$ & $\begin{array}{l}-0.195 \\
0.229\end{array}$ & 1 & & & \\
\hline CRAR & $\begin{array}{l}-0.004 \\
0.978\end{array}$ & $\begin{array}{l}.502^{* *} \\
0.001\end{array}$ & $\begin{array}{l}-0.117 \\
0.472\end{array}$ & $\begin{array}{l}-0.05 \\
0.757\end{array}$ & $\begin{array}{l}-0.056 \\
0.733\end{array}$ & $\begin{array}{l}-0.097 \\
0.552\end{array}$ & $\begin{array}{l}-0.033 \\
0.842\end{array}$ & 1 & & \\
\hline growth & $\begin{array}{l}-0.063 \\
0.701\end{array}$ & $\begin{array}{l}0.112 \\
0.492\end{array}$ & $\begin{array}{l}-0.096 \\
0.557\end{array}$ & $\begin{array}{l}-.391^{*} \\
0.013\end{array}$ & $\begin{array}{l}-0.288 \\
0.072\end{array}$ & $\begin{array}{l}-0.214 \\
0.186\end{array}$ & $\begin{array}{l}0.194 \\
0.231\end{array}$ & $\begin{array}{l}0.204 \\
0.207\end{array}$ & 1 & \\
\hline NPA & $\begin{array}{l}-.500^{* *} \\
0.001\end{array}$ & $\begin{array}{l}-.650^{* *} \\
0\end{array}$ & $\begin{array}{l}-0.03 \\
0.853\end{array}$ & $\begin{array}{l}0.187 \\
0.248\end{array}$ & $\begin{array}{l}-0.045 \\
0.781\end{array}$ & $\begin{array}{l}0.033 \\
0.84\end{array}$ & $\begin{array}{l}0.111 \\
0.495\end{array}$ & $\begin{array}{l}-.334^{*} \\
0.035\end{array}$ & $\begin{array}{l}-0.295 \\
0.064\end{array}$ & 1 \\
\hline tier I & $\begin{array}{l}-0.111 \\
0.494\end{array}$ & $\begin{array}{l}.427^{* *} \\
0.006\end{array}$ & $\begin{array}{l}-0.186 \\
0.252\end{array}$ & $\begin{array}{l}-0.177 \\
0.275\end{array}$ & $\begin{array}{l}-0.063 \\
0.699 \\
\end{array}$ & $\begin{array}{l}-0.014 \\
0.931 \\
\end{array}$ & $\begin{array}{l}0.231 \\
0.151 \\
\end{array}$ & $\begin{array}{l}.783^{* *} \\
0 \\
\end{array}$ & $\begin{array}{l}0.223 \\
0.167 \\
\end{array}$ & $\begin{array}{l}-.323^{*} 1 \\
0.042\end{array}$ \\
\hline
\end{tabular}

**. Correlation is significant at the 0.01 level (2-tailed).

*. Correlation is significant at the 0.05 level (2-tailed)

\section{Correlation Analysis}

The degree of association among the variables of the study is explored in Table 2 with Pearson correlation. The results indicate that ROA has a positive correlation with Tier I capital and CRAR (both significant at 99\% confidence level) implying that for banks, capital adequacy plays a key role in the determination of profitability. Capitalization and profitability are considered as indicators of banks' risk management efficiency and provides cushion against losses not covered by current earnings (Olalekan \& Adeyinka, 2013). Further, the correlation analysis reveals that board size has negative correlation with growth rate which is significant at $95 \%$ confidence level which points out that larger board are generally less effective than smaller boards because of communication and co-ordination problems (Lipton \& Lorsch, 1992; Yermack, 1996). It's worthy to note that NPA have a negative correlation with Tier I capital and CRAR (both 
significant at 95\% confidence level), probably when bank do not lend it leads to higher CRAR which results to lower NPA and vice-versa. The bivariate analysis is intriguing because the results provide a basis for interpreting the results of regression.

\section{Multiple Regression Analysis}

In order to examine the hypothesis 1,2 , and 3 that whether there is any impact of corporate governance factors on banks' performance. The results of regression have been summarized in table 3 for each year of study. In year 2008-09 ID and CRAR have a significant positive effect on bank performance measured by ROE. CRAR and share have a significant positive effect and CEO duality has a negative effect on bank performance measured by ROA. The $\mathrm{R}^{2}$ is $17.52 \%$, $26.05 \%$ and $18.14 \%$ indicates the variation caused by CG variables on ROE, ROA and ROI respectively, though it's typically less as in the case of cross sectional panel data. In year 200910 we found significant positive influence of CRAR and share on ROA and ROI respectively. Similarly CEO duality has a negative impact on bank performance measured by ROI and ROE. Furthermore in year 2010-11 we found significant positive relation between CRAR and ROA and between board size and ROE. ROI is negatively influenced by attendance and positively influenced by shares. It has been observed that CRAR has a significant positive impact on bank performance measured as ROE and ROA in the year 2011-12. The implications of the findings based on multiple regression analysis indicates that ID has a positive effect on bank performance (ROE), so we may state that the null hypothesis $\mathrm{H}_{4}$ may be rejected which states that bank performance does not affected by number of independent directors on board. Thus this study corroborates the argumentation that more number of independent directors in board increase the performance of bank (Cornett, McNutt, \& Tehraian, 2009). But it does not show any significant relationship with ROA and ROI. The CRAR has a positive effect on profitability as measured by ROA and ROE, so the null hypothesis $\mathrm{H}_{1}$ may be rejected that the capital adequacy ratio has no influence on bank performance. The results are consistent with previous research conducted by Unite and Sullivan (2003); Naceur and Kandil (2009); Beltratti and Stulz (2009); Utama and Musa (2011). Thus, the existence of the bank's capital is an important instrument to preserve the liquidity of the bank (Siamat 2004). This finding supports the central bank's effort to strengthen bank's capital base by increasing the minimum capital adequacy ratio from $8 \%$ to $9 \%$ (In accordance with Basel III norms, Indian banks will have to maintain their capital adequacy ratio at nine percent as against the minimum recommended requirement of eight per cent). However we fail to find the positive effect of CRAR on ROI. Further it is found that shareholding of NEDs has a positive effect on bank performance measured by ROA and ROI as the large shareholders come with different sets of skills and preferences when the invest in the companies. And with the power these shareholders wield, their skills and preferences can have significant effects on bank profitability. Therefore null hypothesis $\mathrm{H}_{5}$ may be rejected that number of shares held by NEDs has no impact on bank performance. These results are also supported by Bhagat and Bolton (2008) and Ehikioya (2009). Meanwhile, CEO duality has a negative influence on bank performance measure by ROE, ROA and ROI, suggesting the need to separate the position of CEO and chairperson to insure the independence of board for optimum bank performance. Therefore, this result is consistent with the view that when one person holds the seat of CEO and chairman, there would be a more serious agency problem and reduction in the boards' effectiveness of monitoring top management (Fama \& Jensen, 1983). Thus we conclude that null hypothesis $\mathrm{H}_{7}$ may be rejected that bank performance does not affected by CEO duality. Board size has a positive effect on ROE, so we may reject the null hypothesis $\mathrm{H}_{2}$ which states that 
board size has no impact on bank performance. The result is consistent with the proposition that firms with larger boards are more efficient in their asset utilization and they are more likely to discipline their CEO for poor performance than smaller boards. This result is also supported by Adams and Mehran (2003) who find that the banking sector has a larger board size compared to the manufacturing sector and finally led to increased bank performance. Attendance has negative effect on ROI.

It may be because of higher attendance in board meetings leads to high expense in the payment of sitting fee which is given out of the profits of the corporate. Therefore, we may reject the null hypothesis $\mathrm{H}_{3}$ which states that attendance rate of directors at board meeting has no influence on bank performance which is also supported by Spong and Sullivan (2012) who said that average attendance rate is not statistically related to bank risk. Board size and attendance are statistically significant only in the year 2010-11. However the OLS method has not indicated high level of $\mathrm{R}^{2}$ which means that bank profitability is also affected by other factors too. it is always high and increasing when bank profitability is measure by ROA except year 2009-10 and it becomes $44.01 \%$ in 2011-12. Thus on the basis of the results below we conclude that CG practice has the positive influence on the bank performance, so we may state that our objective that corporate governance affects banks' performance hold truth. Therefore this result corroborates the previous studies (Adams \& Mehran, 2003; Bhagat \& Bolton, 2008; Brown \& Caylor, 2006). The finding of the study are in congruence with the results of Utama and Musa (2011) and Wang et al. (2012) who showed that CG practice have the positive influence on bank performance in pre-crisis period. Similarly, Beltratti and Stulz (2009) proved that banks with stronger CG mechanism were associated with higher profitability during the crisis period. Hence our results are consistent with the previous studies' results of pre-crisis period as well as during the crisis. During the study period 2008-09 to 2011-12 there were 1322 NED whose education qualification needs to be collected. Due to scarcity of data we got hold of the profile of 968 NEDs i.e., 73.22\%. There were $33.16 \%$ graduate, $32.02 \%$ were post graduate, $14.46 \%$ had the doctoral degree and $20.35 \%$ of them were professionals during the study period. Hence, the basis of these results and their profiles which were given in the annual reports we may state that Indian banking has well educated and experienced non-executive directors. 
Table 3: Relationship Between Bank Performance And Corporate Governance

\begin{tabular}{|c|c|c|c|c|c|c|c|c|c|c|c|c|}
\hline \multirow[b]{3}{*}{ Variable } & \multicolumn{6}{|l|}{ 2008-09 } & \multicolumn{6}{|l|}{$2009-10$} \\
\hline & \multicolumn{2}{|l|}{ ROE } & \multicolumn{2}{|l|}{ ROA } & \multicolumn{2}{|l|}{ ROI } & \multicolumn{2}{|l|}{ ROE } & \multicolumn{2}{|l|}{ ROA } & \multicolumn{2}{|l|}{ ROI } \\
\hline & Coefficient & Prob. & Coefficient $\mathrm{P}$ & Prob. & Coefficient & Prob. & Coefficient & Prob. & Coefficient & Prob. & Coefficient & Prob. \\
\hline $\mathrm{C}$ & 5.90 & 0.669 & $-1.02 \quad 0$ & 0.257 & 4.73 & 0.000 & 2.22 & 0.855 & -0.96 & 0.299 & 7.46 & 0.000 \\
\hline BOARD_SIZE & -0.66 & 0.462 & -0.04 & 0.511 & 0.12 & 0.110 & 1.10 & 0.238 & 0.10 & 0.169 & -0.03 & 0.681 \\
\hline ATTENDĀANCE & 0.76 & 0.397 & 0.06 & 0.339 & -0.04 & 0.563 & -0.99 & 0.260 & -0.09 & 0.187 & -0.05 & 0.494 \\
\hline SHARES & 1.52 & 0.614 & 0.34 & 0.086 & 0.17 & 0.497 & -1.02 & 0.695 & -0.01 & 0.951 & 0.54 & 0.019 \\
\hline ID & 0.17 & 0.041 & 0.01 & 0.196 & 0.01 & 0.240 & 0.14 & 0.110 & 0.00 & 0.469 & 0.00 & 0.652 \\
\hline CRAR & 0.01 & 0.987 & 0.11 & 0.012 & 0.06 & 0.302 & 0.25 & 0.690 & 0.10 & 0.035 & -0.01 & 0.902 \\
\hline CEO_DUALITY & -3.43 & 0.252 & -0.34 & 0.079 & -0.30 & 0.220 & -5.53 & 0.050 & -0.24 & 0.250 & -0.60 & 0.013 \\
\hline R-squared & 0.175 & & 0.261 & & 0.181 & & 0.223 & & 0.219 & & 0.287 & \\
\hline \multirow[t]{3}{*}{ Adjusted R-squared } & 0.025 & & 0.126 & & 0.033 & & 0.082 & & 0.077 & & 0.158 & \\
\hline & $2010-11$ & & & & & & 2011-12 & & & & & \\
\hline & ROE & & $\mathrm{ROA}$ & & ROI & & ROE & & ROA & & ROI & \\
\hline Variable & Coefficient & Prob. & Coefficien & nt Prob. & Coefficient & it Prob. & Coefficient & Prob. & Coefficient & t Prob. & Coefficient & Prob. \\
\hline $\mathrm{C}$ & 0.80 & 0.944 & -1.26 & 0.107 & 7.19 & 0.000 & -13.96 & 0.292 & -1.30 & 0.122 & 7.60 & 0.000 \\
\hline BOARD_SIZE & 1.10 & 0.055 & 0.06 & 0.125 & 0.03 & 0.490 & 0.70 & 0.369 & -0.01 & 0.836 & -0.03 & 0.658 \\
\hline ATTENDANCE & -0.51 & 0.365 & -0.01 & 0.730 & -0.08 & 0.096 & 0.37 & 0.663 & 0.04 & 0.433 & 0.06 & 0.414 \\
\hline SHARES & 2.51 & 0.164 & 0.19 & 0.126 & 0.29 & 0.056 & 0.51 & 0.863 & -0.03 & 0.868 & 0.25 & 0.304 \\
\hline ID & 0.07 & 0.309 & 0.00 & 0.792 & 0.01 & 0.357 & -0.02 & 0.800 & 0.00 & 0.470 & 0.00 & 0.700 \\
\hline CRAR & 0.32 & 0.510 & 0.12 & 0.001 & -0.03 & 0.420 & 1.52 & 0.033 & 0.17 & 0.000 & -0.02 & 0.767 \\
\hline CEO_DUALITY & -3.04 & 0.109 & 0.02 & 0.848 & -0.23 & 0.139 & -2.66 & 0.317 & -0.01 & 0.963 & 0.04 & 0.854 \\
\hline R-squared & 0.176 & & 0.377 & & 0.206 & & 0.224 & & 0.440 & & 0.096 & \\
\hline Adjusted R-squared & 0.026 & & 0.264 & & 0.062 & & 0.083 & & 0.338 & & -0.068 & \\
\hline
\end{tabular}


Table 4: Relationship between Education qualification and Bank performance

\begin{tabular}{lcccccc}
\hline & ROE & & \multicolumn{2}{c}{ ROA } & \multicolumn{2}{c}{ ROI } \\
Variable & Coefficient & Prob. & Coefficient & Prob. & Coefficient & Prob. \\
\hline C & 17.69802 & 0 & 1.178575 & 0 & 6.889504 & 0 \\
GR & 0.755548 & 0.7133 & 0.164205 & 0.2667 & -0.046601 & 0.7476 \\
PG & -3.355024 & 0.1168 & -0.322562 & 0.0371 & 0.018956 & 0.8981 \\
DOCT & -0.663105 & 0.7394 & -0.123134 & 0.3887 & 0.227273 & 0.1118 \\
PROF & -2.381705 & 0.2214 & -0.189098 & 0.1746 & -0.083131 & 0.5413 \\
R $^{2}$ & 0.090266 & 0.156748 & \multicolumn{2}{c}{0.086517} \\
Adjusted R & & \multicolumn{2}{c}{0.060377} & \multicolumn{2}{c}{-0.017881} \\
\hline
\end{tabular}

Hereafter in the succeeding section we checked the hypothesis 4,5 and 6 that whether there is any impact of education qualification of NEDs on bank performance. The relationship predicted in equations 4, 5 and 6 is shown in the regression results produced in the above table 4 which exhibit the relationship between education qualification of NEDs and bank performance measured by ROE, ROA and ROI. It is found that in equation 4 GR is positively and PG, DOCT and PROF are negatively related with profitability (ROE) but not statistically significant. In equation 5 GR and profitability (ROA) is directly (positively) related as the slope coefficient of the model is positive (0.164). While the $\mathrm{P}$ value is 0.2667 which do not reject the null hypothesis, meaning that it is not statistically significant. PG, DOCT and PROF are inversely related to the profitability as there signs are negative $(-0.322,-0.123$ and -0.189 respectively). The null hypothesis is not rejected by DOCT and PROF as they are not statistically significant except PG which is statistically significant at $5 \%$ as the p value is 0.0371 . In equation 1.6 where ROI is the dependent variable, GR and PROF are negatively related to profitability, but not statistically significant. The PG and DOCT are directly related to profitability but are not statistically significant. The results indicate that we fail to reject the null hypothesis $\mathrm{H}_{07}$ which states that education qualification of NEDs has no influence on bank performance as none of them has positive significant impact on profitability. In brief it may be said from the above results that profitability is not affected by education qualification and other factors like finance experience, management experience (Hau \& Thum, 2009), government background, business background, age and gender influence the profitability. Also according to Banking regulation Act 1949 the composition of Board of Directors comprising members with demonstrable professional and other experience in specific sectors like agriculture, rural economy, cooperation, SSI, law, etc.

\section{Construction of Corporate Governance Index (CGI)}

In order to find out the quality of corporate governance mechanism of Indian banks during the post crisis we have constructed the corporate governance index (CGI). The data from annual reports has been used to identify the mechanisms and practices of corporate governance. We have used the dummy variables which are not legally enforced by clause 49 of the Listing Agreements with the Stock Exchanges. The dummy variables which are included in CGI are as the CEO duality and chairman of the non- mandatory committees is NED, then variables are binary. Similarly if the complete disclosure of the information regarding education qualification of NEDs, percentage of independent directors in the board and percentage of shareholding by NEDs, ownership pattern, ED's and NED's compensation are there in annual reports then the variables take value 1 , otherwise 0 . The CGI's values can range from 0 to 12 . An important note for the study is the fact that if in the index a bank presents a low level of corporate governance 
quality in a particular year, it does not mean that the bank actually has bad level of CG and if a bank ranked highly in the index, it does not mean that the bank has a good quality of CG mechanism. What we have tried to find in the study is the level of CG quality perceived by an outsider without an insider means, tools or accessibility to information during the study's time period 2008-09 to 2011-12. The sample includes 40 listed banks, so the total no. of observations is 160. The frequencies for the CGI have been calculated and then divided these frequencies into three groups; the first group of observations is located at values 0 to 4, the second at values 5 to 8 and third group at values 9 to 12 . The group leads to $11.9 \%$ of the sample is ranked among the first group, while $60 \%$ is ranked among the second group and only $28.1 \%$ among the third group. If we join the second and third group then it covered $88.1 \%$ of the sample.

\section{Independent-Samples T-Test}

For testing the hypothesis that there is no difference between the CG practice of public and private sector banks of India Independent t-test has been used. The independent t-test compares the means between two unrelated groups on the same continuous, dependent variable. For the equal-variance $t$ test the assumptions are: the observations should be independent, random samples from normal distributions with the same population variance. For this t-test we have taken the mean value of all the dummy variables which are shown in table 7 . So these variables collectively make the CG structure of a bank, which we want to test. Type of bank is the independent variable in this test which means for public banks we write 1 and for private bank we write 0 and the corporate governance mechanism is the dependent variable.

$\mathrm{H}_{08}: \mu 1-\mu 2=0(\mu 1=\mu 2)$ There is no difference in the mean value of corporate governance mechanism between public banks and private sector banks.

$\mathrm{H}_{09}: \mu 1-\mu 2 \neq 0(\mu 1 \neq \mu 2)$ There is a difference in the mean value of corporate governance mechanism between public banks and private sector banks.

Testing the hypothesis as a two-tailed test with $\alpha=0.05$ the $t$ value of -8.436 falls within the critical region defined by the critical value of \pm 2.048 and the $p$-value is less than alpha of 0.05 . Therefore we may state that there is no difference in the mean value of corporate governance mechanism between public banks and private banks. As private banks have more mean value of corporate governance $($ mean $=9.1094, \mathrm{sd}=1.77475)$ than public $($ mean $=5.1562, \mathrm{sd}=1.19513)$. So we may state a significant statistical difference in these averages. Therefore we may say that there is no difference between $\mathrm{CG}$ practice of listed public and private sector banks of India.

\section{Conclusion}

We observed that the results of regression are not consistent during the study period but collectively the results point out that Indian banks' performance is positively affected by board size, number of independent directors, CRAR, and number of shares held by NEDs and it is negatively influenced by attendance and CEO duality. Hence we may conclude that the main factors of corporate governance of banks in India are board size, percentage of independent directors in the board, CRAR, number of shares held by NEDs and non CEO duality. We may say that the study supports the Agency theory of corporate governance as bank performance is negatively related with CEO duality. Hence we may also state that CG factors have positive impact on Indian banks' performance during post crisis period, which is supported by the pre- 
crisis period results as well as during the crisis period. The implication of these findings is that corporate governance practices enhances the banks' performance and the findings supports the central banks' efforts to enhance the CG practice in the Indian banking sectors. The study reveals that the performance and corporate governance variables of the listed Indian banks have been in a relatively comfortable position as read in other developed nations during the post subprime crisis period may be due to prudent regulation of the Reserve Bank of India and not so prevalent derivative holdings of banks. The study has tested the underlying assumptions of OLS model and on the basis of overall results we found that the error term is normally distributed and homoscedastic. Further there is no auto correlation in the error term. Panel data is inappropriate in this model as the error term do not reflect hetroscedasticity and autocorrelation. Therefore the research can be used for further decision making. The study gives a scope of further research by extending the model and including more variables like age and gender of board member and role, responsibility, eligibility criteria for appointment of independent NEDs.

\section{References}

Adams, R., \& Mehran, H. (2003). Is corporate governance different for bank holding companies. Economic Policy Review, 9(1), 123-142.

Andres, P. D., \& Vallelado, E. (2008). Corporate governance in banking: The role of the board of directors. Journal of Banking \& Finance, 32(12), 2570-2580.

Beltratti, A., \& Stulz, R. M. (2009). Why did some banks perform better during the credit crisis? A cross-country study of the impact of governance and regulation. The National Bureau of Economic Research 105(1), 133.

Berger, A. N., Clarke, G. R., Cull, R., Klapper, L., \& Udell, G. F. (2005). Corporate governance and bank performance: A joint analysis of the static, selection, and dynamic effects of domestic, foreign, and state ownership. Journal of Banking \& Finance, 29(8), 2179-2221.

Bhagat, S., \& Bolton, B. (2008). Corporate governance and firm performance. Journal of Corporate Finance, 14(3), 257-273.

Brown, L. D., \& Caylor, M. L. (2006). Corporate governance and firm valuation. Journal of Accounting and Public Policy, 25(4), 409-434.

Chambers, C. (2009). Another day another culprit: Corporate governance-Is it to blame for the banking crisis? Business Law Review, 30(12), 264-269.

Cheung, Y. L., Stouraitis, A., \& Tan, W. (2010). Does the quality of corporate governance affect firm valuation and risk? Evidence from a corporate governance scorecard in Hong Kong. International Review of Finance, 10(4), 403-432.

Cornett, M. M., McNutt, J. J., \& Tehranian, H. (2009). Corporate governance and earnings management at large US bank holding companies. Journal of Corporate Finance, 15(4), 412-430.

Dalwai, T. A. R., Rohaida, B., \& Siti Z. A. R. (2015). A critical review of relationship between corporate governance and firm performance: GCC banking sector perspective. Corporate Governance, 15(1),18-30.

De Jonghe, O., Disli, M., \& Schoors, K. (2012). Corporate governance, opaque bank activities, and risk/return efficiency: Pre-and post-crisis evidence from Turkey. Journal of Financial Services Research, 41(1-2), 5180.

Donaldson, L., \& Davis, J. H. (1991). Stewardship theory or agency theory: CEO governance and shareholder returns. Australian Journal of Management, 16(1), 49-64.

Ehikioya, B. I. (2009). Corporate governance structure and firm performance in developing economies: Evidence from Nigeria. Corporate Governance, 9(3), 231-243.

Fama, E. F., \& Jensen, M. C. (1983). Separation of ownership and control. The Journal of Law and Economics, 26(2), 301-325.

Garcia-Meca, E., Garcia- Sanchez, I. M., \& Martnez- Ferrero, J. (2015). Board diversity and its effect on bank performance: An international analysis. Journal of Banking and Finance 53, 202-214.

Gillan, S., Hartzell, J. C., \& Starks, L. (2003). Explaining corporate governance: Board, bylaws and charter provisions. Retrieved from http://papers.ssrn.com/sol3/papers.cfm?abstract_id=442740.

Hau, H., \& Thum, M. (2009). Subprime crisis and board (in-) competence: Private versus public banks in Germany. Economic Policy, 24(60), 701-752. 
Jensen, M. (1993). The modern industrial revolution, exit and the failure of internal control system, Journal of Finance, 48(3), 831-880.

Jensen, M. C., \& Meckling, W. H. (1976). Theory of the firm: Managerial behavior, agency costs and ownership structure. Journal of Financial Economics, 3(4), 305-360.

Kanojia S. (2010). Active board monitoring and performance of banks: A study of public and private sector banks. New Delhi, India: Macmillan.

Kim, P. K., \& Rasiah, D. (2010). Relationship between corporate governance and bank performance in Malaysia during the pre and post Asian financial crisis. European Journal of Economics, Finance and Administrative Sciences, 21(1), 39-63.

Li, J., \& Harrison, J. R. (2008). Corporate governance and national culture: A multi-country study. Corporate Governance, 8(5), 607-621.

Lin, X., \& Zhang, Y. (2009). Bank ownership reform and bank performance in China. Journal of Banking \& Finance, 33(1), 20-29.

Lipton, M., \& Lorch, J. W. (1992). A modest proposal for improved corporate governance. The Business Lawyer, 48(1), 59-77.

Mace, M. M. (1971). Directors myth and reality, Boston, MA: Harvard Business School.

Madhani, P. M. (2015). Managing salesforce performance: Behavior versus outcome measures. Compensation \& Benefits Review, 47(2), 81-90.

Naceur, S. B., \& Kandil, M. (2009). The impact of capital requirements on banks' cost of intermediation and performance: The case of Egypt. Journal of Economics and Business, 61(1), 70-89.

Nippani, S., Vinjamury, R. S., \& Bathala, C. (2008). Bank size and corporate governance structure. The IUP Journal of Bank Management, 7(4), 7-17.

Olalekan, A., \& Adeyinka, S. (2013). Capital adequacy and banks' profitability: an empirical evidence from Nigeria. American International Journal of Contemporary Research, 3(10), 87-93.

Panchasara, D. B. M., \& Bharadia, M. H. S. (2013). Corporate governance disclosure practices and firm performance: Evidence from Indian banks. Paradigm, 17(1-2), 88-98.

Pfeffer, J. (1972). Size and composition of corporate boards of director: The organization and its environment, Administrative Science Quarterly, 17(2), 1829-1853.

Qu, B., Jiang, C., \& Zhang, J. (2012). Concentration, risk, and bank performance: Evidence from emerging economies. London, UK: Middlesex University.

Ross, A., \& Crossan, K. (2012). A review of the influence of corporate governance on the banking crises in the United Kingdom and Germany. Corporate Governance, 12(2), 215-225.

Sarpal, S. (2014). Interrelationship among selected voluntary board practices in corporate governance: Evidence from India. Indian Journal of Corporate Governance, 7(2), 95-121.

Saunders, A., \& Cornett, M. M. (2006). Financial institutions management: A risk management approach. New York, NY: McGraw-Hill/Irwin.

Sharma, J. P. (2010a). Corporate governance failure: A Case Study of Satyam. Indian Journal of Corporate Governance, 3(2), 136-175.

Sharma, J. P. (2010b). Corporate governance, business ethics \& CSR. New Delhi, India: Ane Books.

Shleifer, A., \& Vishny, R. W. (1997). A survey of corporate governance. The Journal of Finance, 52(2), 737-783.

Siamat, D. (2004). Manajemen lembaga keuangan edisi keempat. Jakarta, Indonesia: Lembaga Penerbit Fakultas Ekonomi Universitas.

Spong, K., \& Sullivan, R. J. (2012). Bank ownership and risk taking: Improving corporate governance in banking after the crisis. In J. R. Barth, C. Lin, \& C. Wihlborg (Eds.), Research handbook on international banking and governance (pp. 163-179). Cheltenham, UK: Edward Elgar.

Unite, A. A., \& Sullivan, M. J. (2003). The effect of foreign entry and ownership structure on the Philippine domestic banking market. Journal of Banking \& Finance, 27(12), 2323-2345.

Utama, C. A., \& Musa, H. (2011). The causality between corporate governance practice and bank performance: Empirical evidence from Indonesia. Gadjah Mada International Journal of Business, 13(3), 227-247.

Wang, W. K., Lu, W. M., \& Lin, Y. L. (2012). Does corporate governance play an important role in BHC performance? Evidence from the US. Economic Modelling, 29(3), 751-760.

Yermack, D. (1996). Higher market valuation of companies with a small board of directors. Journal of financial economics, 40(2), 185-211. 